\title{
Developing Xenostandards for Microbiological Safety: New Zealand Experience
}

\author{
O. Garkavenko, S. Wynyard, D. Nathu and R. Elliott \\ Living Cell Technologies \\ New Zealand
}

\section{Introduction}

Human patients have the potential to become infected with animal viruses following xenotransplantation. Concerns have also been raised that in a worst case scenario, pathogens originating from pig donors may adapt and then propagate to the wider public resulting in a new epidemic (Fiane, Mollnes, \& Degre, 2000; Fishman, 2001a; Onions et al., 2000; Patience, Wilkinson, \& Weiss, 1997; Weiss, 2003). The likelihood that cross-species infection may occur is enhanced in a xenotransplantation setting because normal host defences such as skin and mucosal surfaces are bypassed and direct contact between donor and recipient cells is maintained for extended periods of time (O'Rourke, 2000). Similarly for applications that use immunosuppression to prevent xenograft rejection, host complementmediated immunity is circumvented (Takeuchi, Magre \& Patience, 2005). Currently pigs are recognised as the most popular choice as donor animals due in part to their ostensibly lower infectious risk (compared with non-human primates), excellent breeding potential, comparable organ size, physiological similarity, amenability to genetic modification, non contentious public perception and the relatively moderate costs associated with their maintenance (Sachs, Sykes, Robson, \& Cooper, 2001). In terms of pig pathogens it has been determined that the preponderance of fungi, bacteria and parasites can be excluded as major risk factors simply by the use of good animal husbandry practices in Specific Pathogen Free (SPF) herds (Ye, Niekrasz, Kosanke, Welsh, Jordan et al, 1994). Consequently viruses are recognised as the predominant infectious agent for zoonosis owing to their rapid rate of evolution and excellent adaptive competence within new hosts. Precedents for cross-species infection of viruses and adaptation in humans are numerous and include several notorious examples, notably AIDS (Gao, Bailes, Robertson, Chen, Rodenburg et al, 1999) and avian influenza [reviewed in (Alexander \& Brown, 2000)]. Although pigs are not always a natural reservoir for exogenous viruses, it has been hypothesised that swine may act as "mixing vessels" for adaptation to human hosts, as is certainly the case for avian viruses such as Severe Acute Respiratory Syndrome (SARS) (Bush, 2004).

Recommendations to minimize cross-species infection stipulate that donor pigs should be maintained in quarantined facilities and monitored for the presence of exogenous pathogens. This type of program requires significant resources so there is considerable incentive to monitor only those viruses that are relevant. Several comprehensive reviews have been published describing zoonotic agents in pigs that may potentially cause disease in 
transplant recipients and theoretically the population at large (Fishman, 2001a, 2001b; Mueller, Takeuchi, Mattiuzzo, \& Scobie, 2011; Scobie \& Takeuchi, 2009; Takeuchi et al, 2005). A particularly valuable resource is the report in the journal Xenotransplantation by Shuurman (2009) that offers a consensus view of organisms that should be excluded from donor pigs. The most important pathogens are reported to be swine influenza viruses belonging to the influenza A genus, Nipah virus, Marburgvirus and Ebolavirus of the Filoviridae family, rotaviruses, parvoviruses, hepatitis $\mathrm{E}$ and herpesviruses such as porcine circovirus type 2 (PCV2) and porcine lymphotrophic herpes virus type 2 (PLHV2).

In New Zealand a very deliberate strategy was employed in order to maximise patient safety by ensuring that these viruses and other pathogens were absent in a donor herd destined for clinical trials. Two important goals were considered integral to the success of the New Zealand approach. The first goal was to ensure the safety of donor material and was achieved by utilising the following steps: (1) investigating the health status of the New Zealand pig population; (2) developing and implementing an algorithm for herd selection; (3) establishing a program to characterise pig endogenous retrovirus; (4) defining a testing schedule to maintain the specific pathogen-free (SPF) status of the donor herd; (5) certifying the health of all donor animals and (6) certifying the safety of the final product. The second goal required the implementation of a robust monitoring program for patient follow-up post-transplant. In this case specific emphasis was placed upon the development of reliable and sensitive assays to detect pig pathogens in humans as well as developing a network of collaborative reference laboratories. Important also was the establishment of a xeno-microbiology laboratory and its accreditation as a medical diagnostic laboratory to guarantee the highest diagnostic standards. Using this strategy regulatory approval was obtained to begin the first clinical trials using insulinproducing cells (DIABECELL®) for the treatment of Type I Diabetes (http://www.lctglobal.com/lctdiabecell-diabetes-treatment.php).

\section{Determining infections relevant to xenotransplantation in NZ}

The Public Health Service Guidelines on Infectious Disease Issues in Xenotransplantation states that monitoring programs for source animals should be tailored to specific geographical areas (U.S Food and Drug [FDA], 2001). This recommendation implies knowledge of the local pig infection profile and in particular, knowledge of virus infections potentially relevant to xenotransplantation. The health status of the NZ pig population is considered to be favourable thanks largely to its geographic remoteness and strict animal health control policies. Unlike many countries NZ remains free from infectious vesicular diseases such as foot and mouth, vesicular stomatitis and vesicular exanthema. Notable infections like rabies, Brucella suis, swine fever, pseudorabies and spongiform encephalopathy are also absent. Routine screening protocols for a source herd intended for xenotransplantation may encompass up to 45 different pathogens (H. J. Schuurman, 2009) many of which are common to veterinary practices. However, for the NZ pig population very limited data was initially available regarding viruses such as Porcine Cytomegalovirus (PCMV), Porcine Lymphotrophic Herpesvirus (PLHV), Encephalomyocarditis Virus (EMCV), Porcine Circovirus Virus (PCV) and pig Hepatitis E Virus (HEV). In order to extend the data regarding the prevalence of these potentially zoonotic viruses an investigatory screening program was performed that tested representatives from herds 
throughout NZ (Garkavenko, Elliott, \& Croxson, 2005; Garkavenko, Muzina, et al., 2004; Garkavenko et al., 2001). This information led to a significantly improved understanding of the infection profile within NZ pig breeds and facilitated the development of a screening protocol for viruses that were particularly relevant to xenotransplantation. Numerous NZ pig herds intended as a source of islet cells for transplantation were comprehensively assessed according to this screening protocol.

Having established the epidemiology of our test panel of viruses in NZ pigs, a further examination was performed in one-week old piglets (the donor age group from which islet cells are harvested). All one-week-old piglets were free of the majority of tested viruses. This finding implies that infection with PCMV, PLHV and HEV takes place perior post-natal and that despite the presence of infection within a herd, new-born piglets and their tissues may remain virus-free. This conclusion is in contrast with another study in which the PLHV virus was shown to be vertically transmitted although it should be noted that this type of transmission phenomenon is considered to be a rare event (Tucker et al., 2003). The presence of PCV2 in tissues and faecal samples of one-week-old piglets was an unexpected result. Although it was shown that this virus can be transmitted vertically (Bogdan et al., 2001.; Ladekjaer-Mikkelson et al., 2001; O'Connor et al., 2001; Sanchez, Nauwynck, McNeilly, Allan, \& Pensaert, 2001), there is a common view that this virus is associated with severe pathology in new-born piglets, and its vertical transmission is also a rare event.

Three factors must be considered when assessing the infectious risk of PCV2 associated with xenotransplantation: (1) the ubiquity of the PCV type 2 virus (Celera \& Carasova, 2002; Garkavenko et al., 2005; Kim et al., 2002; Labarque, Nauwynck, Mesu, \& Pesaert, 2000; Trujano, Iglesias, Segales, \& Palacios, 2001; Wattrang et al., 2002); (2) the potential that the virus might be transmitted vertically without showing any sign of abnormality (Garkavenko, Croxson, et al., 2004) and (3) transmission of the virus occurs in human cells in vitro (Hattermann, 2002, unpublished data), and in experimental mice in vivo (Kiupel et al., 2001). Despite evidence that caesarean section and barrier rearing techniques are effective in excluding PCV and PLHV from pig populations, these interventions do not guarantee the exclusion of all viruses from a pig herd (Tucker et al., 2003). While each of these factors requires further intensive study, it seems reasonable to suggest that any source herd intended for xenotransplantation must be free from PCV and PLHV.

\section{Selection criteria for xenotransplantation donors}

The microbiological 'xenostandard' demands the absence of identifiable infectious agents in the source herd. A NZ donor herd that fulfilled this standard was found through a monitoring program that required the completion of several key tasks. This included a viral profile assessment of the pig population within the country, identification of a specific source herd, development of safety criteria including a plan to manage positive animals and finally, implementation of a multilevel monitoring schedule encompassing pig founders through to the final product. For the New Zealand herd an algorithm to determine whether source animals were suitable for xenotransplantation was developed (see Figure 1). This algorithm stipulates that if an agent capable of infecting human cells cannot be eradicated from the herd then an assessment of risk versus benefit must be made. Using this algorithm 
it became apparent that pigs from the Auckland Islands (AI) represented the ideal donor herd.

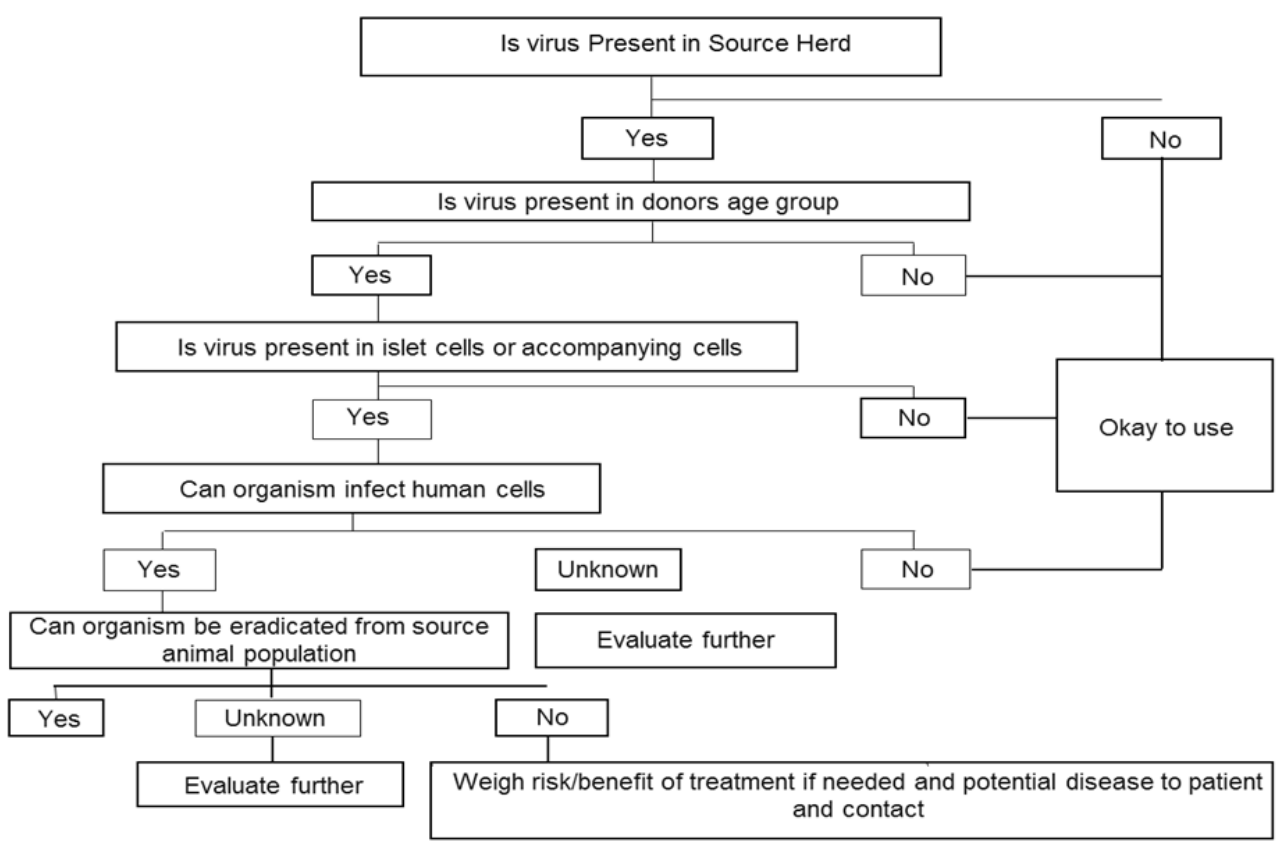

Fig. 1. Algorithm for donor herd selection

\subsection{The Auckland Island donor herd}

The Auckland Islands are a group of islands to the south of mainland New Zealand. In 1807 individual pigs were first introduced to the island as a source of food for whalers and shipwrecked sailors. Over subsequent decades these animals were reported to be thriving leading to further releases in 1840, 1842 and 1890. By the end of the nineteenth century a strong feral pig population had been established that was to remain isolated for the next hundred years. By the mid 1990's these animals were marked for eradication by the New Zealand Department of Conservation as part of a program to restore the natural ecosystems on the island. Consequently the Rare Breeds Conservation Society of New Zealand (RBCSNZ) attempted to preserve the breed in captivity. In 1999 a RBCSNZ expedition caught and removed seventeen pigs, including several pregnant sows, from Auckland Island, transferring them to Invercargill, New Zealand. These animals were subsequently acquired by the private biotech company Living Cell Technologies for the purposes of providing donor material for cell transplantation in humans for the treatment of disease. Currently these animals are maintained within quarantined facilities with one founder herd of approximately 40 animals kept in Invercargill, New Zealand and a second smaller donor herd of 15 animals located in Kumeu, Auckland, New Zealand. These animals as well as the cellular products derived from them are subject to a rigorous testing schedule for an extensive list of pathogens (Table 1). 


\begin{tabular}{|c|c|c|c|c|}
\hline Pathogen/Disease & Type & Frequency & NZ Status & $\begin{array}{l}\text { Herd } \\
\text { Status }\end{array}$ \\
\hline Porcine Circovirus Type 1 & Virus & Quarterly & Ubiquitous & Absent \\
\hline Porcine Circovirus Type 2 & DNA virus & Annually & Not present & Absent \\
\hline $\begin{array}{c}\text { Porcine Lymphotrophic } \\
\text { Herpesvirus Type } 2\end{array}$ & DNA virus & Quarterly & Ubiquitous & Absent \\
\hline Porcine Cytomegalovirus & DNA virus & Quarterly & Ubiquitous & Absent \\
\hline Toxoplasma gondii & $\begin{array}{c}\text { Parasitic } \\
\text { protozoan }\end{array}$ & $\begin{array}{l}\text { As } \\
\text { Required }\end{array}$ & Ubiquitous & Absent \\
\hline Porcine Hepatitis E virus & RNA virus & Annually & Ubiquitous & Absent \\
\hline Rotavirus & RNA virus & Annually & Ubiquitous & Absent \\
\hline Reovirus & RNA virus & Annually & Ubiquitous & Absent \\
\hline Porcine Enterovirus Type 1 & RNA virus & Annually & Ubiquitous & Absent \\
\hline Porcine Enterovirus Type 3 & RNA virus & Annually & Ubiquitous & Absent \\
\hline $\begin{array}{c}\text { Porcine } \\
\text { Encephalomyocarditis Virus }\end{array}$ & RNA virus & Annually & Ubiquitous & Absent \\
\hline $\begin{array}{c}\text { Mycoplasma } \\
\text { hyopneumoniae }\end{array}$ & Bacterium & Annually & Ubiquitous & Absent \\
\hline Bovine Virus Diarrhea & RNA virus & Annually & Ubiquitous & Absent \\
\hline Aujesky's Disease & RNA virus & Annually & Not present & Absent \\
\hline Porcine Parvovirus & DNA virus & Quarterly & Ubiquitous & Absent \\
\hline $\begin{array}{l}\text { Porcine Reproductive and } \\
\text { Respiratory Syndrome Virus }\end{array}$ & RNA virus & Annually & Not present & Absent \\
\hline Leptospira hardjo & Bacterium & Quarterly & Ubiquitous & Absent \\
\hline Leptospira pomona & Bacterium & Quarterly & Ubiquitous & Absent \\
\hline Leptospira tarrasovi & Bacterium & Quarterly & Ubiquitous & Absent \\
\hline Campylobacter & Bacterium & Annually & Ubiquitous & Absent \\
\hline Coccidia (Isospora) & $\begin{array}{l}\text { Parasitic } \\
\text { protozoan }\end{array}$ & Annually & Ubiquitous & Absent \\
\hline Cryptosporidium & $\begin{array}{l}\text { Parasitic } \\
\text { protozoan }\end{array}$ & Annually & Ubiquitous & Absent \\
\hline Yersinia & Bacterium & Annually & Ubiquitous & Absent \\
\hline E.coli K88 & Bacterium & Annually & Ubiquitous & Absent \\
\hline Salmonella & Bacterium & Annually & Ubiquitous & Absent \\
\hline
\end{tabular}

Table 1. List of pathogens tested for in the NZ Auckland Island donor herd. 


\subsection{Multilevel monitoring}

A key facet of the 'selection algorithm' is that a multilevel monitoring process is adopted that begins with the regular screening (see table 1) of every individual pig within the donor herd. For certain pathogens such as PCV2, PLHV2 and PCMV sampling maybe performed from multiple tissues including pancreas and peripheral blood leukocytes (PBL). In the case of HEV both blood serum and faeces are processed. This is followed by the screening of all the sows' pre and post farrowing as well as the screening of each piglet donor (see table 2 for tests performed). Prior to surgery and removal of organs each piglet is examined for signs of infection. Any abnormalities are noted and in certain cases further consultation maybe sort from veterinary specialists. A strict policy is enforced to exclude even slightly suspect piglets from contributing donor material. Following removal of donor material each piglet is subject to a full post mortem by veterinary pathologists. Lastly the transplant product itself is screened immediately prior to transplantation. This final clearance is mandatory before the product can be released for transplantation. Such a comprehensive schedule of testing was judged necessary to assure the microbiological safety of xenografts and to satisfy NZ regulatory authorities.

\begin{tabular}{ccc} 
Sows & Piglets & Injected product \\
\hline (pre- and post-farrowing) & HEV & Toxoplasma PCR \\
PPV & Toxoplasma serology & PCV2 \\
Mycoplasma & Post-mortem autopsy & PLHV \\
Toxoplasma & PCV2* & PCMV \\
HEV & PLHV2* & HEV \\
PLHV & PCMV* $^{*}$ & Mycoplasma \\
PCV2 & & \\
PCMV & &
\end{tabular}

Table 2. List of porcine microorganisms for multi-level screening program. *PCR is performed on DNA extracted from both peripheral blood leukocytes and pancreas tissue.

\section{Porcine Endogenous Retrovirus (PERV) - Developing a standard approach}

In comparison to exogenous viruses a unique problem is posed by endogenous retroviruses (ERV). In pigs this pathogen is known as Porcine Endogenous Retrovirus (PERV) and is ubiquitous to all pig species studied to date. Endogenous retroviruses can be distinguished from exogenous types by their presence as genomic components that do not present pathology in their natural host (Stoye, Le Tissier, Takeuchi, Patience, \& Weiss, 1998). Moreover, endogenous retroviruses behave like normal cellular genes in that they are inherited by the offspring and not acquired by infection. Accordingly PERV cannot be removed by conventional barrier methods instead requiring more elaborate strategies such as the selective breeding of pigs with favourable PERV genetic characteristics (Garkavenko, Wynyard, Nathu, Muzina, Muzina et al, 2008; Garkavenko, Wynyard, Nathu, Simond, Muzina et al, 2008; Stoye et al, 1998), or the development of vaccines to protect against PERV transmission or the inhibition of PERV expression by RNA interference using PERV-specific short hairpin RNA (shRNA) and retroviral vectors [reviewed in (Denner, 2008)]. Like most retroviruses PERV has an element of unpredictability in regards to its transmission potential. The concern exists that retroviral transmission may occur 'silently' by means of an 
undetectable recombination event, oncogenesis or alteration in gene regulation resulting in pathology that does not manifest until decades later. Such transmission is typical for gammaretroviruses and xenotransplantation could provide the right environment for selection of variants that can efficiently infect the human population. Numerous studies have been performed examining the risk of PERV transmission as it relates to xenotransplantation with the consensus that PERV must be considered an endogenous agent to be reduced or excluded where possible in animals destined for clinical use (H.J. Schuurman \& Pierson, 2008; Taylor, 2008; Wilson, 2008).

\subsection{PERV infectivity in vitro - The gold standard}

With regard to PERV infectious characteristics, a standard infectivity method can be applied to check the infectivity of primary tissues such as peripheral blood mononuclear cells (PBMC) and islets derived from SPF pigs (Patience, Wilkinson, et al., 1997; Takeuchi et al., 1998). Such data is necessary because PCR for either the PERV pol or PERV env region does not always provide information on the transmission characteristics of PERV. In fact recombinant PERV is most often detected in transmission studies by co-culturing primary pig cells with target human cell lines as was performed in the NZ SPF herd. To ensure the release of infectious PERV particles (if any), tested cells were mitogenically stimulated prior to co-culture with standard susceptible cell lines 293 (to elucidate xeno-tropic PERV) and St-Iowa (to elucidate eco-tropic PERV). Although mitogenic stimulation enhanced proliferation of all tested cells, no evidence of PERV transmission was detected in the infectivity test with both human and pig target cells using PBMC or islet cells isolated from the New Zealand SPF pigs (Garkavenko, Wynyard, Nathu, Muzina, et al., 2008; Garkavenko, Wynyard, Nathu, Simond, et al., 2008). Thus it was concluded that the New Zealand SPF pigs could be classified as non-transmitters for PERV, possessing the "null" transmission phenotype. The term "null", as coined by (Wood et al, 2004), simply means that despite the presence of PERV-A, PERV-B and PERV-C sequences in the genome of these pigs they lack the ability to infect human or pig cells in vitro. This method must be considered the gold standard for determining PERV infectious risk and should be considered compulsory when evaluating new donor herds.

One aspect that can complicate the issue of transmission phenotype is the potential for the transmission status of an animal to change over time. Indeed, data has shown that miniature swine do not maintain their transmission status. For example Wood et al demonstrated that during one 14 month interval, several adolescent miniature swine that were initially capable of infecting pig cells only (non-transmitters) eventually infected human cells thus converting to the transmitter phenotype (Wood et al., 2004). It is unclear if this phenomenon is applicable for other pig breeds, nevertheless any monitoring program of donor SPF herds should include a periodic screening for infectious PERV. Founder animals in New Zealand are tested annually or biennially for PERV infectivity by co-culturing with target cell lines and data has shown that these animals have retained their PERV null phenotype for more than 6 years (Wynyard, 2011).

\subsection{PERV expression and RT activity}

In addition to studying in vitro co-culture infectivity it is recommended that the PERV viral load and RT activity is measured in donor blood plasma. During the characterisation of the 
New Zealand SPF herd PERV viral load in donor blood plasma was measured by real-time PCR using a methodology similar to that described by Dieckhoff et al (2009). RT activity that would indicate retroviral activity and therefore the presence of retroviral particles was also measured in the blood of the donors using a C-Type RT kit (Garkavenko, Wynyard, Nathu, Muzina, et al., 2008; Garkavenko, Wynyard, Nathu, Simond, et al., 2008). No evidence of PERV expression or RT activity in pig donors' blood plasma or from stimulated PBMC was found.

\subsection{PERV gene dosage (copy number)}

Pigs that possess a low number of PERV provirus within their genome will theoretically pose less infectious risk than those with a high copy number. This is because the majority of PERV sequences appear to be either defective or deleted, i.e., they contain only one or two intact retro- viral open reading frames of gag, pol and env (Bosch, Arnauld, \& Jestin, 2000; Czauderna, Fischer, Boller, Kurth, \& Tonjes, 2000; Herring et al., 2001; Niebert, RogelGaillard, Chardon, \& Tonjes, 2002). Consequently PERV proviral copy number is another important characteristic that should be investigated when assessing a donor herd for infectious risk. This data can be obtained using a real-time PCR absolute quantification methodology. If this is not feasible then a laboratory may employ the simpler PCR based limited dilution assay (PLDA). PLDA has been widely used to quantify different target molecules, including human immunodeficiency virus copy number (Rodrigo, Goracke, Rowhanian, \& Mullins, 1997). The New Zealand SPF herd has been screened using both methods (Wynyard, 2011; Wynyard, Garkavenko, \& Elliott, 2011) for which a high concordance was observed. PERV copy number in NZ SPF pigs varied from 3 to 68 copies per cell with an average copy number of 17.6 and were found to be not statistically different from the NZ landrace breed or more interestingly the Miniature Swine breed that are known to infect human cells in vitro (Patience, 1997; Takeuchi, 1998). These techniques provide a sensitive and reliable method to specifically identify animals with low PERV copy number ( $<10$ copies per cell) that are suitable for further selective breeding. Numerous such individual pigs have been identified in the AI pig herd and are currently being bred to reduce PERV infectious risk.

\subsection{PERV recombinants}

Another important aspect to consider is the ability of PERV-A and PERV-C to recombine as there is evidence that PERV A/C recombinants show higher titres when cultured in human cells in vitro (Bartosch et al., 2004; Oldmixon et al., 2002; Wilson, Wong, VanBrocklin, \& Federspiel, 2000; Wood et al., 2004). As discussed earlier, using the co-culture infectivity test with human HEK293 and swine St Iowa target cell lines, it was established that primary cells (PBMCs) from NZ donor pigs do not release either xeno- or ecotropic infective viruses (Garkavenko, Wynyard, Nathu, Muzina, et al., 2008; Garkavenko, Wynyard, Nathu, Simond, et al., 2008). To support the lack of transmission from this herd, animals were tested for and found to lack the genomic presence of high titre recombinant PERV A/C. A potential PERV-C locus that may contribute to recombination and the generation of transmissible PERV sequences in miniature swine was also found to be absent. These animals also appear to be transcriptionally inactive for PERV-C as PERV-C RNA could not be detected despite possessing PERV-C proviral sequences. 


\subsection{PERV infectivity in vivo}

An assessment of PERV infectious risk can be made at multiple levels beginning with the ability to release virus from the cells of a xenografted organ. Subsequent analysis would need to characterise the virus's ability to cause viremia by revealing productive infection within the recipient cells. Final recognition as a public health hazard would require demonstration of the infectious virus circulating within the patients' bodily fluids. While the ability of PERV to infect human cells in vitro is well documented, less is actually known about PERV infectious potential in vivo and its capacity to cause disease. To address this question numerous animal models have been investigated. The most common models have been concentrated around the use of non-human primates (NHP) or small animals such as severe combined immunodeficiency (SCID) mice. Unfortunately both models have proven problematic and in the case of SCID mice somewhat contentious. In NHP, conflicting results have been reported as regards the resistance of NHP cells to PERV infection, with some studies reporting non-permissiveness (Martin, Steinhoff, Kiessig, Chikobava, Anssar et al, 1999; Patience et al, 1997; Takeuchi et al, 1998; Wilson et al, 2000) and others suggesting susceptibility (Blusch, Patience, Takeuchi, Templin, Von Der Helm et al, 2000; Specke, Tacke, Boller, Schwendemann \& Denner, 2001; Templin, Schroder, Simon, Laaff, Kohl et al, 2000). For mice the situation is more complicated. Originally it was discovered that PERV, produced from pig pancreatic cells and transplanted into SCID mice, could infect mouse tissues in vivo. However, the virus produced appeared to be transcriptionally inactive, signifying a non-productive infection (van der Laan, Lockey, Griffeth, Frasier, Wilson et al, 2000). Subsequent analysis revealed that this was not a true infection but rather evidence of pseudotyping involving the collaboration of mouse (endogenous xenotropic MLV) and PERV retroviral elements (Martina, Kurian, Cherqui, Evanoff, Wilson et al, 2005). In terms of overall success, despite several studies demonstrating the transmission of PERV in vivo (Argaw, ColonMoran \& Wilson, 2004; Martina, Marcucci, Cherqui, Szabo, Drysdale et al, 2006; Popp, Mann, Milburn, Gibbs, McCullagh et al, 2007), no report has conclusively demonstrated productive infection (Denner, Specke, Karlas, Chodnevskaja, Meyer et al, 2008; HermidaPrieto, Domenech, Moscoso, Diaz, Ishii et al, 2007; Levy, Argaw, Wilson, Brooks, Sandstrom et al, 2007; Moscoso, Hermida-Prieto, Manez, Lopez-Pelaez, Centeno et al, 2005; Paradis, Langford, Long, Heneine, Sandstrom et al, 1999; Specke, Schuurman, Plesker, Coulibaly, Ozel et al, 2002). In terms of in vivo transmission from the AI pig herd no evidence of PERV infection was found in non-human primates following transplantation of islet cells (Garkavenko, Dieckhoff, Wynyard, Denner, Elliott et al, 2008) or in twelve human patients sampled from the New Zealand clinical trial (Wynyard, 2011).

Such a predominance of data against PERV infection in vivo begs the question as to whether PERV is of real importance. On the other hand it may just be a case of having not yet found a suitable animal model. It is worth noting that the difficulties associated with PERV in vivo infection may also be attributed to the inconsistency of methods used for PERV detection in recipients. Indeed the detection of all PERV subtypes, especially PERVA/C, may not be adequately covered by currently employed PCR and serological methodologies. Establishing quality testing practices therefore becomes vital. 


\section{Patient follow up and laboratory standards}

Approval for clinical trials in xenotransplantation requires comprehensive regulation and approval by government authorities. Crucial to any successful application is demonstration that the methodologies employed to test both donor animals and xenograft recipients are current and accurate. The Molecular Diagnostic Laboratory responsible for testing the New Zealand SPF donor herd and transplant patients employs both serological (ELISA, Late Agglutination Test) and molecular techniques (PCR, real-time PCR) as part of its testing program. However the preferred methodology is a multiplex High Resolution Melting (HRM) real-time PCR similar to that described in (Wynyard, 2011). In this study the superior melting properties of the HRM chemistry enable the simultaneous amplification of sequences for PERV pol, Cytochrome Oxidase II (a pig cell marker) and a heterologous internal control in a single multiplexed reaction. This assay has been employed successfully to screen 12 xenograft recipients of porcine islets to exclude PERV infection whilst simultaneously checking for template integrity, PCR inhibition and microchimerism. Research groups expecting to perform xeno-testing must be prepared to show competencies with nucleic acid methodologies preferably with expertise in both veterinary and medical diagnostic fields. For pathogens that lack commercially available tests or where in-house capabilities are insufficient then a network of reference laboratories and collaborators maybe employed to perform the tests instead. All assays should be suitably validated to ensure accuracy, reproducibility, specificity and sensitivity (both analytical and where possible diagnostic) as expected from any medical diagnostic laboratory (American Association of Veterinary Laboratory Diagnosticians, 2010; Raymaekers, Bakkus, Boone, de Rijke, El Housni et al, 2011). It is important that assays for pathogens that are screened in donor animals show equal efficacy when tested from human tissues and validation protocols should account for this. Controls are mandatory and it is recommended that suitable internal controls are incorporated to improve assay reliability (Hoorfar, Malorny, Abdulmawjood, Cook, Wagner et al, 2004). For example in the New Zealand diagnostic laboratory tissues destined for real-time PCR analysis are routinely spiked with a heterologous internal control that can be used to infer nucleic acid integrity and PCR inhibition (Wynyard, 2011; assays in preparation for publication).

To achieve the highest diagnostic standards it is advisable that laboratories expecting to perform xenomicrobiology testing are accredited to international standards. This will facilitate the use of suitable methods and that laboratory staff are trained and competent to perform each assay. Moreover, accreditation ensures that a suitable QA/QC program is put in place to guarantee that results are reliable and can be trusted. The NZ testing laboratory is audited annually and registered with International Accreditation New Zealand (IANZ). Accreditation is maintained to the ISO15189:2007 standard. It is important to note that for the screening of both the herd and recipients that robust protocols for managing positive results are established. This encompasses the confirmatory testing needed to exclude false positives and describes clearly defined communication lines for reporting. Reporting contacts may include the animal facilities, executive management, pig handlers or in the case of positive results for non-endemic pathogens, the involvement of government departments responsible for biosecurity, animal welfare and public health. Full documentation (integral to the accreditation process) is essential for providing traceability when subject to auditing by regulatory bodies. 


\section{Conclusions}

Any xenotransplantation project should consider a comprehensive safety program that includes two key aspects - donor monitoring and patients' follow-up. Initial identification of donor herds suitable for xenotransplantation requires a comprehensive understanding of viral epidemiology within pig populations and an understanding of the relevant viruses as dictated by the geographical area. A clear decision making process is required to exclude animals that carry infectious agents that ultimately requires a risk versus benefit analysis. Upon the selection of suitable pig donor herd a multilevel screening program is required that tests donor material from breeding animals at the herd level through to the final product. Strategies for management of positive animals must be in place to minimize the risk to the donor herd and transplant recipients. PERV remains the central safety consideration in xenotransplantation. It is very important to develop a standard approach towards the characterization of PERV infectious potential within a potential donor herd. Such a benchmark allows for the comparison of PERV characteristics from pig donors of different backgrounds and ensures the selection of techniques and methods that are reliable and practical for the industry. To effectively characterize PERV in source animals requires a rigorous PERV screening program as has been implemented in a New Zealand specific pathogen free (SPF) pig herd. The key elements of this program should consist of: (a) testing for in vitro infectivity of both eco- and xenotropic viruses using standard cell culture infectivity methods (Patience, Takeuchi, \& Weiss, 1997); (b) measuring reverse transcriptase (RT) activity and PERV viral expression in donors' blood plasma (Dieckhoff et al., 2009; Garkavenko, Wynyard, Nathu, Muzina, et al., 2008; Garkavenko, Wynyard, Nathu, Simond, et al., 2008); (c) measuring the PERV proviral copy number per cell (Wynyard, 2011) and (d) testing for the presence or absence of PERV recombinants and a potential PERV-C loci that may contribute to recombination and the generation of highly transmissible PERV sequences (Garkavenko, Wynyard, Nathu, Muzina, et al., 2008; Garkavenko, Wynyard, Nathu, Simond, et al., 2008). These data provide the basis for a selective pig breeding program with the ultimate goal of enhancing the safety of donors for cell transplantation by minimising PERV infectious risk. It should be evident that patient safety relies heavily upon a robust program of monitoring in transplant recipients. It is expected that laboratory practices meet international standards to ensure technical competence and result validity.

The strategies described in this chapter have been successfully applied in New Zealand and proven crucial towards facilitating clinical trials using porcine islets. It is expected that the same strategies will find broad application outside of New Zealand and provide sufficient guidelines to benefit interested parties looking to enter the xenotransplantation field.

\section{References}

Alexander, D. J. \& Brown, I. H. (2000). Recent zoonoses caused by influenza A viruses. Revue scientifique et technique, 19, 97-225.

American Association of Veterinary Laboratory Diagnosticians. (2010). Requirements for an Accredited Veterinary Medical Diagnostic Laboratory. Date of Access: 20 July 2011. Available from: http://www.aavld.org/index.php?option=com_content\&view=article\&id=18\&Ite $\operatorname{mid}=85$ 
Argaw, T.; Colon-Moran, W. \& Wilson, C. A. (2004). Limited infection without evidence of replication by porcine endogenous retrovirus in guinea pigs. Journal of General Virology, 85(Pt 1), 15-19.

Bartosch, B.; Stefanidis, D.; Myers, R.; Weiss, R.; Patience, C. \& Takeuchi, Y. (2004). Evidence and consequence of porcine endogenous retrovirus recombination. Journal of Virology, 78(24), 13880-13890.

Blusch, J. H.; Patience, C.; Takeuchi, Y.; Templin, C. C. R.; Von Der Helm, K.; Steinhoff, G. \& Martin, U. (2000). Infection of Nonhuman Primate Cells by Pig Endogenous Retrovirus. Journal of Virology, 74(16), 7687-7690.

Bogdan, J.; West, K.; Clark, E.; Konoby, C.; Haines, D.; Allan, G.; McNeilly, F.; Meehan, B.; Krakowka, S. \& Ellis, J. A. (2001). Association of porcine circovirus 2 with reproductive failure in pigs: A retrospective study. Canadian Veterinary Journal, 42(7), 548-550.

Bosch, S.; Arnauld, C. \& Jestin, A. (2000). Study of full-length porcine endogenous retrovirus genomes with envelope gene polymorphism in a specific-pathogen-free Large White swine herd. Journal of Virology, 74(18), 8575-8581.

Bush, R. M. (2004). Influenza as a model system for studying the cross-species transfer and evolution of the SARS coronavirus. Philosophical Transactions of the Royal Society B: Biological Sciences, 359, 1067-1073.

Celera, V. J. \& Carasova, P. (2002). First evidence of porcine circovirus type 2 (PCV-2) infection of pigs in theCzech Republic by seminested PCR. Journal of veterinary medicine B: Infectious diseases and veterinary public health, 49(3), 155-159.

Czauderna, F.; Fischer, N.; Boller, K.; Kurth, R. \& Tonjes, R. R. (2000). Establishment and characterization of molecular clones of porcine endogenous retroviruses replicating on human cells. Journal of Virology, 74(9), 4028-4038.

Denner, J. (2008). Is porcine endogenous retrovirus (PERV) transmission still relevant? Transplantation Proceedings, 40(2), 587-589.

Denner, J.; Specke, V.; Karlas, A.; Chodnevskaja, I.; Meyer, T.; Moskalenko, V.; Kurth, R. \& Ulrichs, K. (2008). No transmission of porcine endogenous retroviruses (PERVs) in a long-term pig to rat xenotransplantation model and no infection of immunosuppressed rats. Annals of Transplantation, 13(1), 20-31.

Dieckhoff, B.; Kessler, B.; Jobst, D.; Kues, W.; Petersen, B.; Pfeifer, A.; Kurth, R.; Niemann, H.; Wolf, E. \& Denner, J. (2009). Distribution and expression of porcine endogenous retroviruses in multi-transgenic pigs generated for xenotransplantation. Xenotransplantation, 16(2), 64-73.

Dorrschuck, E.; Munk, C. \& Tonjes, R. R. (2008). APOBEC3 proteins and porcine endogenous retroviruses. Transplantation Proceedings, 40(4), 959-961.

Fiane, A. E.; Mollnes, T. E. \& Degre, M. (2000). Pig endogenous retrovirus - a threat to clinical xenotransplantation? Apmis, 108(4), 241-250.

Fishman, J. A. (2001a). Infection in Xenostransplantation. Journal of Cardiac Surgery, 16(5), 363-373.

Fishman, J. A. (2001b). Prevention of infection in xenotransplantation. In J. L. Platt (Ed.), Xenotransplantation. Washington, D.C: ASM Press.

Gao, F.; Bailes, E.; Robertson, D. L.; Chen, Y. L.; Rodenburg, C. M.; Michael, S. F.; Cummins, L. B.; Arthur, L. O.; Peeters, M.; Shaw, G. M.; Sharp, P. M. \& Hahn, B. H. (1999). 
Origin of HIV-1 in the chimpanzee Pan troglodytes troglodytes. Nature, 397(6718), 436-441.

Garkavenko, O.; Croxson, M. C.; Irgang, M.; Karlas, A.; Denner, J. \& Elliott, R. B. (2004). Monitoring for presence of potentially xenotic viruses in recipients of pig islet xenotransplantation. Journal of Clinical Microbiology, 42(11), 5353-5356.

Garkavenko, O.; Dieckhoff, B.; Wynyard, S.; Denner, J.; Elliott, R. B.; Tan, P. L. \& Croxson, M. C. (2008). Absence of Transmission of Potentially Xenotic Viruses in a Prospective Pig to Primate Islet Xenotransplantation Study. Journal of Medical Virology, 80, 2046-2052.

Garkavenko, O.; Elliott, R. B. \& Croxson, M. C. (2005). Identification of pig circovirus type 2 in New Zealand pigs. Transplantation Proceedings, 37(1), 506-509.

Garkavenko, O.; Muzina, M.; Muzina, Z.; Powels, K.; Elliott, R. B. \& Croxson, M. C. (2004). Monitoring for potentially xenozoonotic viruses in New Zealand pigs. Journal of Medical Virology, 72(2), 338-344.

Garkavenko, O.; Obriadina, A.; Meng, J.; Anderson, D. A.; Benard, H. J.; Schroeder, B. A.; Khudyakov, Y. E.; Fields, H. A. \& Croxson, M. C. (2001). Detection and characterisation of swine hepatitis E virus in New Zealand. Journal of Medical Virology, 65(3), 525-529.

Garkavenko, O.; Wynyard, S.; Nathu, D.; Muzina, M.; Muzina, Z.; Scobie, L.; Hector, R. D.; Croxson, M. C.; Tan, P. \& Elliott, B. R. (2008). Porcine endogenous retrovirus transmission characteristics from a designated pathogen-free herd. Transplantation Proceedings, 40(2), 590-593.

Garkavenko, O.; Wynyard, S.; Nathu, D.; Simond, D.; Muzina, M.; Muzina, Z.; Scobie, L.; Hector, R. D.; Croxson, M. C.; Tan, P. \& Elliott, B. R. (2008). Porcine Endogenous Retrovirus (PERV) and its Transmission Characteristics: A Study of the New Zealand Designated Pathogen-Free Herd. Cell Transplantation, 17(12), 1381-1388.

Hermida-Prieto, M.; Domenech, N.; Moscoso, I.; Diaz, T.; Ishii, J.; Salomon, D. R. \& Manez, R. (2007). Lack of cross-species transmission of porcine endogenous retrovirus (PERV) to transplant recipients and abattoir workers in contact with pigs. Transplantation, 84(4), 548-550.

Herring, C.; Quinn, G.; Bower, R.; Parsons, N.; Logan, N. A.; Brawley, A.; Elsome, K.; Whittam, A.; Fernandez-Suarez, X. M.; Cunningham, D.; Onions, D.; Langford, G. \& Scobie, L. (2001). Mapping full-length porcine endogenous retroviruses in a large white pig. Journal of Virology, 75(24), 12252-12265.

Hoorfar, J.; Malorny, B.; Abdulmawjood, A.; Cook, N.; Wagner, M. \& Fach, P. (2004). Practical considerations in design of internal amplification controls for diagnostic PCR assays. Journal of Clinical Microbiology, 42(5), 1863-1868.

Kim, J.; Chung, H. K.; Jung, T.; Cho, W. S.; Choi, C. \& Chae, C. (2002). Postweaning multisystemic wasting syndrome of pigs in Korea: Prevalence, microscopic lesions and coexisting microorganisms. Journal of Veterinary Medical Science, 64(1), 57-62.

Kiupel, M.; Stevenson, G. W.; Choi, J.; Latimer, K. S.; Kanitz, C. L. \& Mittal, S. K. (2001). Viral replication and lesions in BALB/c mice experimentally inoculated with porcine circovirus isolated from a pig with postweaning multisystemic wasting disease. Veterinary Pathology, 38, 74-82. 
Labarque, G. G.; Nauwynck, H. J.; Mesu, A. P. \& Pesaert, M. B. (2000). Seroprevalence of porcine circovirus types 1 and 2 in the Belgian pig population. Veterinary Quarterly, 22(4), 234-236.

Ladekjaer-Mikkelson, A. S.; Nielson, J.; Storgaard, T.; Botner, A.; Allan, G. \& McNeilly, F. (2001). Transplacental infection with PCV-2 associated with reproductive failure in a gilt. Veterinary Record, 148(24), 759-760.

Levy, M. F.; Argaw, T.; Wilson, C. A.; Brooks, J.; Sandstrom, P.; Merks, H.; Logan, J. \& Klintmalm, G. (2007). No evidence of PERV infection in healthcare workers exposed to transgenic porcine liver extracorporeal support. Xenotransplantation, 14(4), 309-315.

Martin, U.; Steinhoff, G.; Kiessig, V.; Chikobava, M.; Anssar, M.; Morschheuser, T.; Lapin, B. \& Haverich, A. (1999). Porcine endogenous retrovirus is transmitted neither in vivo nor in vitro from porcine endothelial cells to baboons. Transplantation Proceedings, 31, 913-914.

Martina, Y.; Kurian, S.; Cherqui, S.; Evanoff, G.; Wilson, C. \& Salomon, D. R. (2005). Pseudotyping of Porcine Endogenous Retrovirus by Xenotropic Murine Leukemia Virus in a Pig Islet Xenotransplantation Model. American Journal of Transplantation 5(8), 1837-1847.

Martina, Y.; Marcucci, K. T.; Cherqui, S.; Szabo, A.; Drysdale, T.; Srinivisan, U.; Wilson, C. A.; Patience, C. \& Salomon, D. R. (2006). Mice transgenic for a human porcine endogenous retrovirus receptor are susceptible to productive viral infection. Journal of Virology, 80(7), 3135-3146.

Moscoso, I.; Hermida-Prieto, M.; Manez, R.; Lopez-Pelaez, E.; Centeno, A.; Diaz, T. M. \& Domenech, N. (2005). Lack of cross-species transmission of porcine endogenous retrovirus in pig-to-baboon xenotransplantation with sustained depletion of antialpha Gal antibodies. Transplantation, 79(7), 777-782.

Mueller, N. J.; Takeuchi, Y.; Mattiuzzo, G. \& Scobie, L. (2011). Microbial safety in xenotransplantation. Current Opinion in Organ Transplantation, 16(2), 201-206.

Niebert, M.; Rogel-Gaillard, C.; Chardon, P. \& Tonjes, R. R. (2002). Characterization of chromosomally assigned replication-competent gamma porcine endogenous retroviruses derived from a large white pig and expression in human cells. Journal of Virology, 76(6), 2714-2720.

O'Connor, B.; Gauvreau, H.; West, K.; Bogdan, J.; Ayroud, M.; Clark, E. G.; C Konoby, Allan, G. \& Ellis, J. A. (2001). Multiple porcine circovirus 2-associated abortions and reproductive failure in a multisite swine production unit. Canadian Veterinary Journal 42, 551-553.

O'Rourke, L. G. (2000). Xenotransplantation. In C. Brown \& C. Bolin (Eds.), Emerging diseases of animals (pp. 59-84). Washington, DC: ASMPress.

Oldmixon, B. A.; Wood, J. C.; Ericsson, T. A.; Wilson, C. A.; White-Scharf, M. E.; Andersson, G.; Greenstein, J. L.; Schuurman, H. \& Patience, C. (2002). Porcine endogenous retrovirus transmission characteristics of an inbred herd of miniature swine. Journal of Virology, 76(6), 3045-3048.

Onions, D.; Cooper, D. K. C.; Alexander, T. J. L.; Brown, C.; Claassen, E.; Foweraker, J. E.; Harris, D. L.; Mahy, B. W.; Minor, P. D.; Osterhaus, A. D.; Pastoret, P. P. \& Yamanouchi, K. (2000). An approach to the control of disease transmission in pigto-human xenotransplantation. Xenotransplantation, 7(2), 143-155. 
Paradis, K.; Langford, G.; Long, Z. F.; Heneine, W.; Sandstrom, P.; Switzer, W. M.; Chapman, L. E., Lockey, C., Onions, D. \& Otto, E. (1999). Search for cross-species transmission of porcine endogenous retrovirus in patients treated with living pig tissue. Science, 285(5431), 1236-1241.

Patience, C.; Takeuchi, Y. \& Weiss, R. A. (1997). Infection of human cells by an endogenous retrovirus of pigs. Nature Medicine, 3(3), 282-286.

Patience, C.; Wilkinson, D. A. \& Weiss, R. A. (1997). Our retroviral heritage. Trends in Genetics, 13(3), 116-120.

Popp, S. K.; Mann, D. A.; Milburn, P. J.; Gibbs, A. J.; McCullagh, P. J.; Wilson, J. D.; Tonjes, R. R. \& Simeonovic, C. J. (2007). Transient transmission of porcine endogenous retrovirus to fetal lambs after pig islet tissue xenotransplantation. Immunology and Cell Biology, 85(3), 238-248.

Raymaekers, M.; Bakkus, M.; Boone, E.; de Rijke, B.; El Housni, H.; Descheemaeker, P.; De Schouwer, P.; Franke, S.; Hillen, F.; Nollet, F.; Soetens, O. \& Vankeerberghen, A. Molecular Diagnostics.be working group. (2011). Reflections and proposals to assure quality in molecular diagnostics. Acta Clinica Belgica. 66(1), 33-41.

Rodrigo, A. G.; Goracke, P. C.; Rowhanian, K. \& Mullins, J. I. (1997). Quantitation of target molecules from polymerase chain reaction-based limiting dilution assays. Aids Research and Human Retroviruses, 13(9), 737-742.

Sachs, D. H.; Sykes, M.; Robson, S. C. \& Cooper, D. K. C. (2001). Xenotransplantation. Advances in Immunology, 79, 129-223.

Sanchez, R. E.; Nauwynck, H. J.; McNeilly, F.; Allan, G. M. \& Pensaert, M. B. (2001). Porcine circovirus infection in swine foetuses inoculated at different stages of gestation. Veterinary Microbiology, 83(2), 169-176.

Schuurman, H. J. (2009). The International Xenotransplantation Association consensus statement on conditions for undertaking clinical trials of porcine islet products in type 1 diabetes--chapter 2: Source pigs. Xenotransplantation, 16(4), 215-222.

Schuurman, H. J. \& Pierson, R. N. I. (2008). Progress towards clinical xenotransplantation. Frontiers in Bioscience, 13, 204-220.

Scobie, L. \& Takeuchi, Y. (2009). Porcine endogenous retrovirus and other viruses in xenotransplantation. Current Opinion in Organ Transplantation, 14(2), 175-179.

Specke, V.; Schuurman, H. J.; Plesker, R.; Coulibaly, C.; Ozel, M.; Langford, G.; Kurth, R. \& Denner, J. (2002). Virus safety in xenotransplantation: first exploratory in vivo studies in small laboratory animals and non-human primates. Transplant Immunology, 9(2-4), 281-288.

Specke, V.; Tacke, S. J.; Boller, K.; Schwendemann, J. \& Denner, J. (2001). Porcine endogenous retroviruses: in vitro host range and attempts to establish small animal models. Journal of General Virology, 82, 837-844.

Stoye, J. P.; Le Tissier, P.; Takeuchi, Y.; Patience, C. \& Weiss, R. A. (1998). Endogenous retroviruses: a potential problem for xenotransplantation? Annals of the New York Academy of Sciences, 862, 67-74.

Takeuchi, Y.; Magre, S. \& Patience, C. (2005). The potential hazards of xenotransplantation: an overview. Revue scientifique et technique, 24(1), 323-334.

Takeuchi, Y.; Patience, C.; Magre, S.; Weiss, R. A.; Banerjee, P. T.; Le Tissier, P. \& Stoye, J. P. (1998). Host range and interference studies of three classes of pig endogenous retrovirus. Journal of Virology, 72(12), 9986-9991. 
Taylor, L. (2008). Xenotransplantation. eMedicine. Retrieved from http:/ /emedicine.medscape.com/article/432418-overview

Templin, C.; Schroder, C.; Simon, A. R.; Laaff, G.; Kohl, J.; Chikobava, M.; Lapin, B.; Steinhoff, G. \& Martin, U. (2000). Analysis of potential porcine endogenous retrovirus transmission to baboon in vitro and in vivo. Transplantation Proceedings, 32, 1163-1164.

Trujano, M.; Iglesias, G.; Segales, J. \& Palacios, J. M. (2001). PCV-2 from emaciated pigs in Mexico. Veterinary Record, 148(25), 792.

Tucker, A. W.; McNeilly, F.; Meehan, B.; Galbraith, D.; McArdle, P. D.; Allan, G. \& Patience, C. (2003). Methods for the exclusion of circoviruses and gammaherpes viruses from pigs. Xenotransplantation, 10, 343-348.

U.S Food and Drug (FDA). (2001, January 23, 2007). PHS Guideline on Infectious Disease Issues in Xenotransplantation. Retrieved December 14, 2007, from http://www.fda.gov/cber/gdlns/xenophs0101.htm.

van der Laan, L. J. W.; Lockey, C.; Griffeth, B. C.; Frasier, F. S.; Wilson, C. A.; Onions, D. E.; Hering, B. J.; Long, Z. F.; Otto, E.; Torbett, B. E. \& Salomon, D. R. (2000). Infection by porcine endogenous retrovirus after islet xenotransplantation in SCID mice. Nature, 407(6800), 90-94.

Wattrang, E.; McNeilly, F.; Allan, G. M.; Greko, C.; Fossum, C. \& Wallgren, P. (2002). Exudative epidermitis and porcine circovirus-2 infection in a Swedish SPF-herd. Veterinary Microbiology, 86(4), 281-293.

Weiss, R. A. (2003). Cross-species infections. Curr Top Microbiol Immunol, 278, 47-71.

Wilson, C. A. (2008). Porcine endogenous retroviruses and xenotransplantation. Cellular and Molecular Life Sciences, 65(21), 3399-3412.

Wilson, C. A.; Wong, S.; VanBrocklin, M. \& Federspiel, M. J. (2000). Extended analysis of the in vitro tropism of porcine endogenous retrovirus. Journal of Virology, 74(1), 49-56.

Wood, J. C.; Quinn, G.; Suling, K. M.; Oldmixon, B. A.; Van Tine, B. A.; Cina, R.; Arn, S.; Huang, C. A.; Scobie, L.; Onions, D. E.; Sachs, D. H.; Schuurman, H. J.; Fishman, J. A. \& Patience, C. (2004). Identification of exogenous forms of human-tropic porcine endogenous retrovirus in miniature Swine. Journal of Virology, 78(5), 2494-2501.

Wynyard, S. (2011). PERV genetic characteristics as selective breeding criteria - developing a pig breed suitable for xenotransplantation. MSc Thesis. University of Auckland, Auckland.

Wynyard, S.; Garkavenko, O. \& Elliott, R. (2011). Multiplex high resolution melting assay for estimation of Porcine Endogenous Retrovirus (PERV) relative gene dosage in pigs and detection of PERV infection in xenograft recipients. Journal of Virological Methods, 175(1), 95-100.

Ye, Y.; Niekrasz, M.; Kosanke, S.; Welsh, R.; Jordan, H. E.; Fox, J. C.; Edwards, W. C.; Maxwell, C. \& Cooper, D. K. C. (1994). The pig as a potential organ donor for man a study of potentially transferable disease from donor pig to recipient man. Transplantation, 57(5), 694-703. 


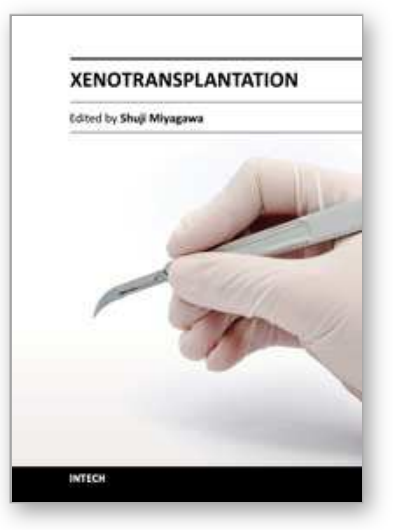

\author{
Xenotransplantation \\ Edited by Prof. Shuji Miyagawa
}

ISBN 978-953-307-997-4

Hard cover, 126 pages

Publisher InTech

Published online 03, February, 2012

Published in print edition February, 2012

Accompanied by the advent of animal cloning, the technique of nuclear transfer produced alpha1,3galactosyltransferase-knockout (Gal-KO) pigs in many institutes, including the ones in Japan, at the beginning of 21 st Century. In addition, the controversy of the risks of PERV has gradually minimized, because of the fact that there are no cases of PERV infections reported in humans. Furthermore, a large clinical wave for islet allotransplantation resumed the interest of xenotransplantation, especially porcine islet transplantation and some exceptions. Clinical trials were done in many countries so far, such as Sweden, China, Mexico, USA (Inventory of Human Xenotransplantation Practices - IXA and HUG in collaboration with WHO). In addition, a new clinical trial was approved by the government, and resumed the porcine islet transplantation research in New Zealand two years ago.

\title{
How to reference
}

In order to correctly reference this scholarly work, feel free to copy and paste the following:

O. Garkavenko, S. Wynyard, D. Nathu and R. Elliott (2012). Developing Xenostandards for Microbiological Safety: New Zealand Experience, Xenotransplantation, Prof. Shuji Miyagawa (Ed.), ISBN: 978-953-307-997-4, InTech, Available from: http://www.intechopen.com/books/xenotransplantation/developing-xenostandards-formicrobiological-safety-new-zealand-experience

\section{INTECH}

open science | open minds

\author{
InTech Europe \\ University Campus STeP Ri \\ Slavka Krautzeka 83/A \\ 51000 Rijeka, Croatia \\ Phone: +385 (51) 770447 \\ Fax: +385 (51) 686166 \\ www.intechopen.com
}

\author{
InTech China \\ Unit 405, Office Block, Hotel Equatorial Shanghai \\ No.65, Yan An Road (West), Shanghai, 200040, China \\ 中国上海市延安西路65号上海国际贵都大饭店办公楼 405 单元 \\ Phone: +86-21-62489820 \\ Fax: $+86-21-62489821$
}


(C) 2012 The Author(s). Licensee IntechOpen. This is an open access article distributed under the terms of the Creative Commons Attribution 3.0 License, which permits unrestricted use, distribution, and reproduction in any medium, provided the original work is properly cited. 